\title{
NILAI-NILAI MORAL DALAM NOVEL HABIBURRAHMAN EL SHIRAZY (TINJAUAN STRUKTURAL GENETIK)
}

\author{
Virry Grinitha1 \\ virrygrinitha@yahoo.co.id
}

\begin{abstract}
The objective of the research is to find out the moral values in Habiburrahman El Shirazy's Novels. The research was conducted using qualitative approach with descriptive method. The data were collected by analyzing, studying, and recording the document. The analysis and interpretation of the data indicate that first, moral values in novel's structure of the novels include human's perspective toward God, such as piety, devout, humble; human's perspective toward themselves such as honest, responsible, healthy, discipline, hard work, confident, logical, critical, creative, innovative, autonomous, curious; human's perspective toward human such as the awareness of their right and duty toward themselves and the others, the obedience of social norms, the appreciation of one's achievements and works, being polite and democratic, and human's perspective toward surroundings such as caring and admiring toward the beauty of nature created by God. Second, Moral values were analyzed through the author's social background indicating the appearance of the novels. Third, moral values from the author's point of view in the novels include human's perspective toward God, themselves, the others, and surroundings. It is recommended that students should read the novels in order to find out the moral values in literary works.
\end{abstract}

Keywords: moral values, novel, genetic structuralism

\begin{abstract}
ABSTRAK
Tujuan penelitian ini ialah untuk mengetahui dan memberikan pemahaman yang lebih mendalam tentang nilai-nilai moral dalam novel karya Habiburrahman El Shirazy ditinjau dari struktural genetik. Penelitian ini menggunakan pendekatan kualitatif dengan metode analisis isi. Pengumpulan data menggunakan teknik analisis dokumentasi, pustaka, dan catat. Analisis interpretasi data menunjukkan (1) adanya nilai-nilai moral dalam struktur novel Ayat Ayat Cinta yang meliputi dimensi manusia dengan Tuhan yaitu religius, dimensi manusia dengan dirinya, dimensi manusia dengan manusia, yaitu sadar akan hak dan kewajiban diri sendiri dan orang lain dan dimensi manusia dengan lingkungan yaitu adanya keperdulian dan kekaguman terhadap keindahan alam yang diciptakan oleh sang pencipta, (2) nilai-nilai moral yang ditinjau dari sudut latar sosial pengarang yang mengkondisikan lahirnya novel Ayat Ayat Cinta; (3) nilai-nilai moral ditinjau dari sudut pandangan dunia pengarang dalam novel Ayat Ayat Cinta yang meliputi dimensi manusia dengan manusia, dimensi manusia dengan dirinya sendiri, dimensi manusia dengan manusia, dan dimensi manusia dengan lingkungan. Penemuan-penemuan membawa ke arah rekomendasi terhadap siswa agar membekali diri dengan berbagai bacaan penunjang lainnya untuk menemukan nilai-nilai moral yang terkandung dalam karya sastra.
\end{abstract}

Kata kunci: Nilai-nilai moral, novel, struktural genetik

1 Guru SMP Negeri Muara Beliti Musi Rawas Sumatera Selatan 


\section{A. Pendahuluan}

Perkembangan dalam bidang pendidikan sangat diperlukan untuk mencerdaskan bangsa Indonesia dan meningkatkan sumber daya manusia yang bertujuan untuk mewujudkan masyarakat yang lebih maju, adil, dan makmur berdasarkan pancasila dan UndangUndang Dasar 1945, serta dapat mewujudkan pembangunan nasional dan penyempurnaan pendidikan nasional sesuai dengan perkembangan Ilmu Pengetahuan dan Teknologi. Untuk mencapai tujuan tersebut tidak mudah, karena perkembangan Ilmu pengetahuan dan Teknologi juga dapat membawa pengaruh negatif bagi masyarakat dan dunia pendidikan, seperti munculnya teknologi informasi berupa internet.Internet menjamur dimana-mana, sekolah-sekolah, kota, bahkan di kampung-kampung.

Akar dari semua tindakan yang jahat dan buruk, tindakan kejahatan terletak pada hilangnya karakter. Menurut Samani dan Herianto (2011:41) karakter yang kuat adalah sandangan fundamental yang memberikan kemampuan kepada populasi manusia untuk hidup bersama dalam kedamaian serta membentuk dunia yang dipenuhi dengan kebaikan dan kebajikan, yang bebas dari kekerasan dan tindakan-tindakan tidak bermoral.
Karakter merupakan nilai-nilai perilaku manusia yang berhubungan dengan Tuhan, diri sendiri, sesama manusia, lingkungan dan kebangsaan, yang terwujud dalam pikiran, sikap, perasaan, perkataan dan perbuatan berdasarkan norma-norma agama, hukum, tata krama, budaya dan adat istiadat. Sedangkan karakter yang diungkapkan Lickona (1992: 56) adalah penerapan nilai-nilai (values in action) karakter mencakup interelasi tiga bagian yaitu: pengetahuan tentang moral (moral feeling), perasaan tentang moral (moral behavior), dan tindakan.

Masalah moral selalu menjadi perbincangan di tengah-tengah masyarakat, permasalahan sastra menjadi medium perekaman keperluan zaman yang memiliki semangat menggerakkan masyarakat ke arah akhlak yang terpuji. Maka salah satu faktor yang dapat mendukung tercapainya tujuan pendidikan nasional yaitu dengan pembelajaran sastra.

Sastra memiliki fungsi yang penting bagi kehidupan. Sejalan dengan itu, pembelajaran sastra dapat dimanfaatkan sebagai alat untuk meningkatkan kepekaan siswa terhadap nilai-nilai kehidupan dan kearifan dalam menghadapi lingkungan, realitas 
kehidupan, dan sikap pendewasaan. Melalui pembelajaran sastra, diharapkan siswa tumbuh menjadi manusia dewasa yang berbudaya, mandiri, sanggup mengekspresikan diri dengan pikiran dan perasaannya dengan baik, berwawasan luas, kritis, berkarakter, halus budi pekerti, dan santun.

Berkaitan dengan kemanfaatan sastra, maka dalam sastra sering ditemukan nilai-nilai yang bermanfaat bagi pembaca, meski seringkali nilai-nilai tersebut disampaikan secara implisit melalui unsur-unsur pembangun cerita. Nilai dalam sastra biasanya mencerminkan pandangan hidup pengarang tentang nilai-nilai kebenaran. Sebagaimana diketahui bahwa salah satu tujuan diciptakannya karya sastra adalah untuk tujuan pengajaran moral. Karya sastra dapat meningkatkan harkat dan martabat manusia sebagai makhluk ciptaan Tuhan yang paling sempurna.

Moral dalam cerita biasanya dimaksudkan sebagai saran yang berhubungan dengan ajaran moral tertentu yang bersifat praktis, yang dapat diambil (dan ditafsirkan) lewat cerita yang bersangkutan dengan masalah kehidupan, seperti sikap, tingkah laku, dan sopan santun pergaulan.

Petunjuk itu bersifat praktis, dapat ditemukan modelnya dalam kehidupan nyata sebagaimana model yang ditampilkan dalam karya lewat tokohtokohnya. Pembelajjaran sastra diharapkan dapat membantu peserta didik dalam memahami, menikmati, dan menghayati karya sastra. Oleh karena itu, guru sebagai pendidik tidak hanya berperan sebagai penyalur pengetahuanpengetahuan sastra saja, tatapi harus mampu mengembangkan pengetahuan tersebut dan membekali peserta didik dengan keahlian mengapresiasi sastra.Memahami dan menikmati nilai yang terkandung dalam karya sastra, atau dikenal dengan apresiasi sastra, tidaklah mudah. Untuk dapat memahami karya sastra diperlukan sekurang-kurangnya modal dasar berupa pengetahuan sastra dan sikap terhadap sastra, termasuk karya sastra yang berbentuk novel.

Novel merupakan salah satu bentuk refleksi dari kesadaran mental pengarang terhadap nilai yang hidup dan berkembang di tengah-tengah masyarakat karena novel tidak pernah lepas dari sistem sosial budaya yang melingkupinya. Dengan demikian, suatu fenomena sosial dapat menjadi salah satu unsur sebuah novel.

Teks sastra sebagai hasil proses sejarah manusia akan bermakna jika dipahami secara menyeluruh dalam hubungan antarbagian teks dan sejarah masyarakat pengarang. Strukturalisme genetik merupakan pendekatan yang 
berkembang atas dasar penolakan terhadap analisis strukturalisme murni. Prinsip dasar strukturalisme genetik adalah bahwa karya sastra lahir karena proses sejarah suatu masyarakat. Penelitian dengan pendekatan strukturalisme genetik senantiasa mempertimbangkan hal-hal yang melatarbelakangi lahirnya karya sastra. Peneliti dalam menganalisis karya yang diteliti dapat menghubungkannya dengan pengarang dan latar

belakang masyarakat. Pemaknaan teks dapat dikaitkan dengan menghubungkannya dengan hal-hal di luar teks. Hal ini didasarkan pada kenyataan bahwa karya sastra lahir karena kegelisahan pengarang dalam melihat realita yang terjadi. Karya sastra kemudian dapat diteliti dari hubungannya dengan sejarah zaman yang melahirkan.

Strukturalisme genetik sebagai pendekatan sosiologi sastra meyakini bahwa terdapat hubungan antara teks sastra dengan hal-hal di luar teks. Hal di luar teks itu adalah pengarang dan masyarakat. Dengan berbagai problema sosial yang dirasakan dan dilihatnya pengarang menuliskannya kembali dalam bentuk imaji artistik dalam bentuk karya sastra. Artinya karya sastra lahir di tengah-tengah masyarakat sebagai hasil imajinasi pengarang yang merupakan refleksi gejala sosial yang ada. Kehadiran karya sastra merupakan bagian dari kehidupan masyarakat.

Dalam novel misalnya, ditemukan struktur kehidupan masyarakat tertentu. Perilaku-perilaku tokoh yang digambarkan pengarang adalah gambaran perilaku manusia yang hidup secara sosial dengan manusia lain. Perilaku sosial tersebut dapat dalam bentuk politik, sosial, ekonomi, religi, dan lainnya. Sastra sebagai wacana merupakan teks yang dapat dilihat sebagai media penghubung pengguna bahasa (masyarakat). Hubungan itu tidak hanya ujaran, tetapi dalam bentuk kesadaran ideologi, aturan (norma), dan kelas (sosial). Teks sastra dalam bentuk objek dan menjadi aksi. Aksi pengarang terhadap realita yang terjadi ini diwujudkan dalam bentuk pandangan pengarang dalam karya sastra.

Pilihan terhadap novel Ayat Ayat Cinta dengan fokus pada nilai-nilai moral tentu beralasan, karena persoalan moral merupakan persoalan universal, yang dipertanyakan oleh siapa saja, di mana saja, kapan saja, dan tentunya relevan dengan kondisi dan keadaan yang terjadi saat ini. Kaitannya antara nilai-nilai moral dan novel-novel Ayat-ayat Cinta terdapat nilai-nilai moral yang harus diperhatikan dalam segala bentuk tindakan dan aktivitas yang dilakukan antara dimensi 
manusia dengan tuhan, dimensi manusia dengan manusia, dimensi manusia dengan dirinya sendiri, dan dimensi manusia dengan lingkungannya.

Dalam penelitian ini, rumusan masalah umum yang akan dijawab, yaitu Bagaimanakah nilai-nilai moral yang digambarkan pengarang dalam novel Ayat-ayat Cinta ditinjau secara struktural genetik? Sedangkan rumusan khusus dalam penelitian ini sebagai berikut. (1) Nilai-nilai moral ditinjau dari sudut struktur novel (struktur tema, struktur alur, struktur tokoh dan penokohan, serta struktur latar) dalam novel Ayat-ayat Cinta karya Habiburrahman El Shirarazy. (2) Nilai-nilai moral ditinjau dari sudut latar sosial pengarang yang mengkondisikan lahirnya novel Ayat-ayat Cinta (keadaan masyarakat pengarang di luar novel, Ditinjau dari sudut agama, dan adat istiadat) karya Habiburrahman El Shirazy. (3) Nila-nilaii moral ditinjau dari sudut pandangan dunia pengarang (riwayat hidup pengarang, pandangan dan pemikiran yang berhubungan dengan pendidikan) dalam novel Ayat-ayat Cinta karya Habiburrahman El Shirazy.

Novel merupakan salah satu karya sastra yang dihasilkan dengan menggunakan bahasa sebagai alat penyampaiannya. Novel sebagai alat untuk mengungkapkan ide, gagasan, pikiran, dan perasaan yang merupakan pandangan pengarang terhadap obyek nyata yang terjadi dalam masyarakat. Rene Wellek (1995:283) menyatakan bahwa novel berkembang dari bentuk naratif non fiksi seperti surat, jurnal, memorial, kronik, atau sejarah (1995:283). Novel dalam pengertian M.M. Bakhtin dan Patrick dalam Hoffman merupakan jenis prosa fiksi yang tidak mempunyai plot tunggal, karakter dan setting seperti yang ada pada sebuah cerita pendek tetapi ia memiliki plot yang kompleks, karakter, konflik dan pengembangan karakter. Sedangkan menurut Klarer, novel zaman sekarang dicirikan dengan istilah 'realisme' dan 'individualisme' demikian dengan meringkas beberapa inovasi dasar dari media yang baru ini, Klarer (2004:9). Novel pada zaman dahulu mempertunjukkan sebuah dimensi alegoris dan kosmik, sedangkan novel modern memberi ciri sendiri dengan menguatkan alur cerita dalam realita geografis dan historis yang berbeda.

Struktur dalam novel merupakan unsur-unsur intrinsik dalam novel. Dalam novel, Rene Wellek membedakan unsurunsur pembentuk novel dalam tiga bagian, antara lain : alur, penokohan, dan latar (1990: 283) Hal ini sejalan dengan Luxembung (1984:29) yang menyatakan bahwa unsur-unsur utama novel terdiri atas alur (plot), tokoh (character), dan latar 
(setting). Selanjutnya Nurgiyantoro (2011:23) mengemukakan bahwa "unsur instrinsik karya sastra terdiri dari peristiwa, plot, penokohan, tema, latar, sudut pandang penceritaan, bahasa atau gaya bahasa, dan lain-lain".

Stanton (2007:7) menyebut tema sebagai makna yang dkandung oleh cerita. Namun menurut Sujiman tidaklah demikian, tema dalam pengertiannya adalah gagasan, ide, atau pikiran utama yang mendasari suatu karya sastra. Ada kalanya tema dinyatakan dengan jelas secara eksplisit (1991:50). Selanjutnya Nurgiyantoro (2010:74) mengatakan ".....tema yang notabene "hanya" berupa makna atau gagasan dasar umum suatu cerita, tak mungkin hadir tanpa unsur bentuk yang menampungnya".

Mengenai alur Aminuddin (2004:83) berpendapat bahwa, "Alur adalah rangkaian peristiwa yang dibentuk oleh tahapan-tahapan peristiwa sehingga menjalin suatu peristiwa yang dihadirkan oleh para pelaku dalam suatu cerita Selanjutnya J. Arthur Honeywell dalam Hoffman (1988:239) berpendapat bahw plot merupakan urutan peristiwa dimana sebuah cerita dibuat yang mempunyai unsur fiksi hubungan sebab akibat satu sama lainnya.

Menurut Nurgiyantoro (2010:167) bahwa istilah tokoh merujuk pada orangnya atau pelaku cerita. Selanjutnya, Aminuddin (2004:79) menyatakan bahwa "pelaku yang mengemban peristiwa dalam cerita fiksi sehingga peristiwa itu mampu menjalin suatu cerita disebut dengan tokoh. Cara pengarang menampilkan tokoh atau pelaku itu disebut dengan penokohan.

Menurut Sudjiman (1991:46) bahwa "Secara sederhana, latar bisa kita pahami sebagai keterangan ruang, waktu, dan suasana terjadinya lakuan dalam karya sastra". Namun, latar tidak melulu terdiri dari elemen waktu dan tempat, tetapi “....latar hadir dengan elemen lain seperti deskripsi tradisi masyarakat, perilaku sosial, karakter, dan pandangan masyarakat ketika karya itu ditulis". Seperti halnya pendapat Nurgiyantoro bahwa latar dalam karya fiksi tidak terbatas pada penempatan lokasi-lokasi tertentu atau sesuatu yang bersifat fisik saja. Melainkan juga yang berwujud tata cara, adat istiadat, kepercayaan, dan nilainilai yang berlaku di tempat yang bersangkutan, Nurgiyantoro (2010:219).

Berdasarkan pendapat Muchlas (2011:41) bahwa karakter dimaknai sebagai cara berpikir dan berperilaku yang khas tiap indivudu untuk hidup dan bekerja sama, baik dalam lingkup keluarga, masyarakat, bangsa, dan Negara. Lickona mendefinisikan orang 
berkarakter sebagai sifat alami seseorang dalam merespon situasi secara bermoral, yang dimanifestasikan dalam tindakan nyata, melalui tingkah laku yang baik, jujur, bertanggung jawab, menghormati orang lain dan karakter mulia lainnya, Lickona (1992:42) Selanjutnya Robert Marine dalam Muchlas (2011:4) mengungkapkan karakter adalah gabungan yang samar-samar antara sikap, perilaku bawaan, dan kemampuan, yang membangun pribadi seseorang.

Goldman mengungkapkan bahwa Strukturalisme genetik berangkat dari hipotesis bahwa semua perilaku manusia merupakan upaya memberikan respon yang berarti terhadap situasi dan kecenderungan akan sesuatu, dan oleh karena itu, menciptakan keseimbangan antara subjek tindakan dan obyek yang disandangnya, yakni lingkungan. Realitas manusia disajikan sebagai proses dua sisi: destrukturasi dari strukturasi lama dan strukturasi dari totalitas baru mampu menciptakan keseimbangan mampu memuaskan tuntutan baru dari kelompokkelompok sosial yang mengelaborasinya

Goldman dalam Faruk (1994:57) mengatakan bahwa karya sastra di samping memiliki unsur otonom, juga tidak bisa lepas dari unsur ekstrinsik. Selanjutnya, Kutha Ratna (2007:123) berpendapat bahwa secara definitif strukturalisme genetik adalah analisis struktur dengan memberikan perhatian terhadap asal-usul karya..

Berdasarkan beberapa pendapat, dapat disimpulakan bahwa strukturalisme genetik adalah analisis struktur yang dilakukan secara instrnsik dan ekstrinsik.

Tujuan penelitian ini adalah untuk memperoleh pemahaman yang mendalam tentang nilai-nilai moral yang terdapat dalam novel Ayat Ayat Cinta karya Habiburrahman El Shirazy, nilai-nilai moral ditinjau dari latar sosial pengarang, dan nilai-nilai moral ditinjau dari sudut pandangan dunia pengarang.

\section{B. Metode Penelitian}

penelitian ini adalah penelitian kualitatif dengan menggunakan metode analisis isi. Analisis isi menurut Emzir (2011:283) merupakan suatu analisis yang mendalam terhadap pesan-pesan tersurat dan tersirat dari semua jenis komunikasi atau konteks tempat, baik dengan teknik kuantitatif maupun kualitatif. Lebih lanjut Emzir menjelaskan bahwa dalam bentuk kualitatif, analisis isi diperuntukkan pada analisis suatu isi kumunikasi berupa percakapan, teks tertulis, wawancara, fotografi, dan lainnya yang dikategorikan dan diklasifikasikan berdasarkan masalah yang diangkat. (2011:284).

Prosedur penelitian dilakukan dengan cara data dikumpulkan dengan 
melakukan pembacaan terhadap Novel Ayat-ayat Cinta, karya Habiburrahman EL Shirazy. Prosedur penelitian yang dilakukan: (1) Membaca dan memahami karya sastra (Novel Ayat-ayat Cinta karya Habiburrahman EL Sharizy). Melakukan identifikasi terhadap novel. (3) Melakukan pengelompokkan atau klasifikasi. (4) Mengumpulkan data tentang latar belakang sosial budaya pengarang dan pandangan dunia pengarang dalam novel Ayat-ayat Cinta karya Habiburrahman EL Shirazy. Teknik analisis data tersebut dilaksanakan dengan cara: (1) pembacaan seluruh isi novel Ayat-ayat Cinta (2) Identifikasi dan analisis data unsur dominan. nilai-nilai moral yang diungkapkan pengarangdalam Ayat-ayat Cinta yang mencakup : dimensi manusia dengan tuhannya, dimensi manusia dengan dirinya sendiri, dimensi manusia dengan manusia, dan dimensi manusia dengan alam Struktur novel Ayatayat Cinta (3) Identifikasi dan analisis data struktur dalam novel-novel karya Habiburrahman El Shirazy ( Ayat-ayat
Cinta yang mencakup: tema, alur, tokoh dan penokohan, latar, amanat, serta gaya bahasa (4) Identifikasi dan analisis data peristiwa-peristiwa sosial yang mengkondisikan lahirnya novel novel Ayat-ayat Cinta (5) Identifikasi dan analisis data mengenai pandangan dunia pengarang dalam novel Ayat-ayat Cinta (6) Identifikasi analisis data struktur dalam novel Ayat-ayat Cinta. Kemudian, untuk menjamin keabsahan data maka dilakukan teknik pengujian dengan cara kredibilitas, transferabilitas, dependabilitas, dan konfirmabilitas.

\section{Hasil Penelitian dan Pembahasan.}

\section{Hasil Penelitian}

Struktur novel Ayat Ayat Cinta hasil penelitian, khususnya nilai-nilai moral yangf ditemukan, menunjukkan adanya dimensi manusia dengan tuhan, dimensi manusia dengan diri sendiri, dimensi dengan manusia, dan dimensi dengan lingkungan. Perhatikan tabel struktur novel berikut:

\begin{tabular}{|c|c|}
\hline Tema & Kepedulian dan cinta \\
\hline Alur & Maju \\
\hline Tokoh dan Penokohan & $\begin{array}{l}\text { - Fahri, seorang pemuda yang berusia } 26 \text { tahun } \\
\text { memasuki usia } 27 \text { tahun, mepunyai karakter rajin } \\
\text { beribadah, cerdas n hafal Alquran, giat belajar, } \\
\text { tanggung jawab, baik hati, sholeh, pemaaf } \\
\text { menepati }\end{array}$ \\
\hline
\end{tabular}




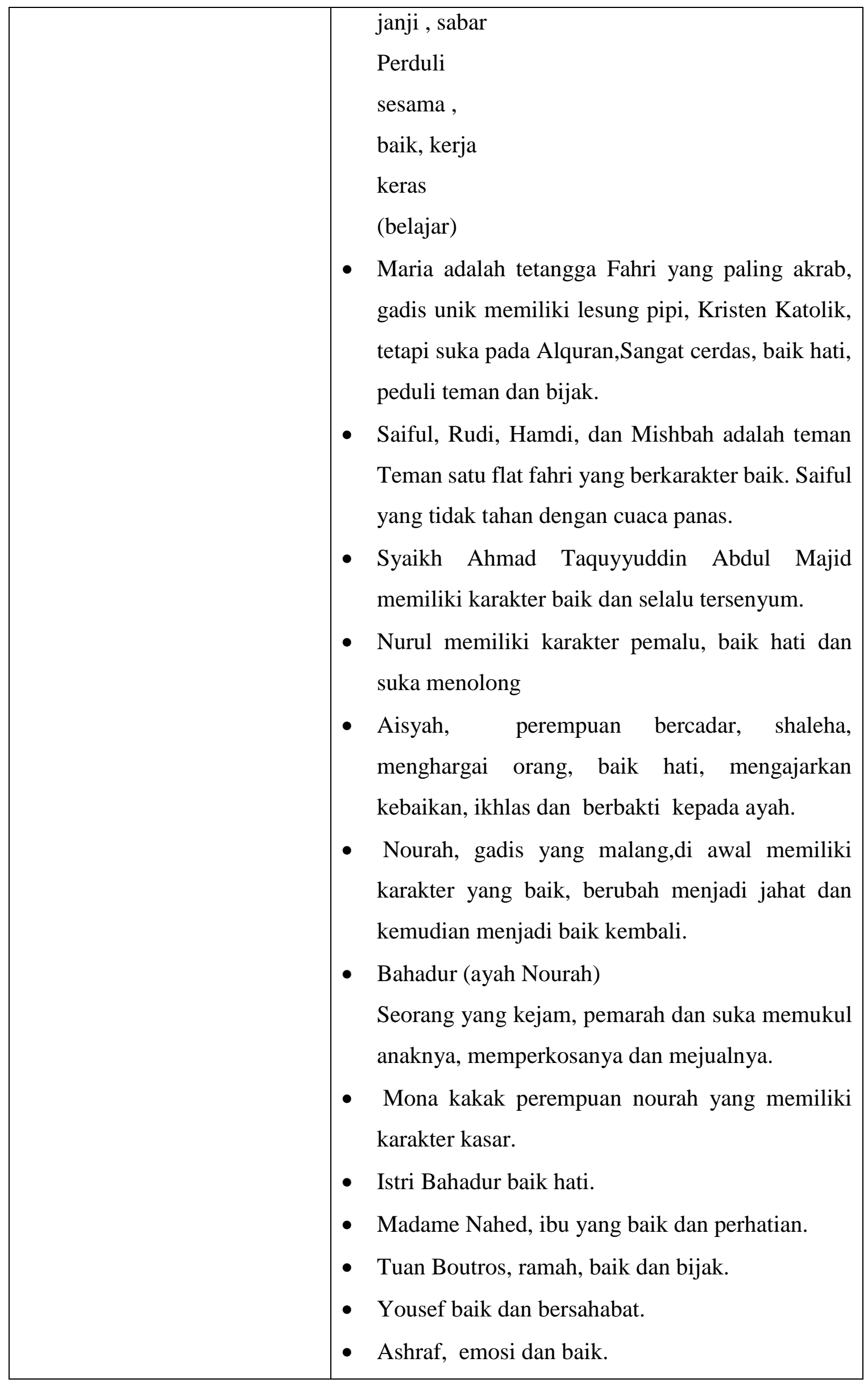




\begin{tabular}{|c|c|}
\hline & $\begin{array}{l}\text { - Alice seorang reporter yang baik hati. } \\
\text { - Eqbal adalah paman Aisah yang memiliki karakter } \\
\text { baik hati dan perhatian serta penyayang } \\
\text { - Ustazh Jalal, baik. } \\
\text { - . Madame Syaima, istri ustazh Jalan berkarakter } \\
\text { baik. } \\
\text { - Polisi 1, polisi 2, dan polisi } 3 \text { memiliki karakter } \\
\text { yang jahat. }\end{array}$ \\
\hline Latar & $\begin{array}{l}\text { - Latar tempat di Mesir Kairo Al-Azhar, flat, } \\
\text { mesjid, metro, SIC, Suthub Apartemen, pasar } \\
\text { Sayeda, Cleopatra restora, Nasional Library, } \\
\text { @lfenia Warnet, rumah sakit, Kamar khusus dan } \\
\text { ruang tamu Syaikh Utsman, Halaman rumah } \\
\text { Eqbal,di ruang tamu, Muhamad Mazhar Steet, } \\
\text { Flat lantai tujuh nomor 21, Alexandria, Hotel San } \\
\text { Stefano, Markas polisi Abbasea } \\
\text { Latar waktu menunujukkan waktu pagi, siang, } \\
\text { sore, dan malam hari. } \\
\text { Latar sosial } \\
\text { a. Kebiasaan di Mesir apabila ada orang } \\
\text { bertengkar dan untuk menurunkan amarahnya } \\
\text { dengan membaca shalawat, penduduknya yang } \\
\text { ramah, penduduknya lemah lembut. } \\
\text { kebiasaan orang desa apabila memperoleh } \\
\text { rizki,maka melalukakan syukuran dengan } \\
\text { membagi-bagikan makanan dengan para } \\
\text { tetangga. } \\
\text { c. Perempuan Jawa sangat setia, perduli pada } \\
\text { keluarga, terlibat sepenuhnya dalam masalah } \\
\text { keluarga, istri ikut memikirkan dapur mengepul }\end{array}$ \\
\hline
\end{tabular}




\begin{tabular}{|l|l|}
\hline & d. Polisi Mesir tidak memakai azas praduga tak \\
bersalah, tapi praduga bersalah. Jika dicurigai \\
langsung dtangkap akan dibebaskan kalau \\
terbukti tak bersalah.
\end{tabular}

\section{Nilai-nilai Moral}

\begin{tabular}{|l|l|}
\hline $\mathbf{1}$ & $\begin{array}{l}\text { Religius, yaitu: taqwa, iman dan } \\
\text { tawaduk. }\end{array}$ \\
\hline $\mathbf{2}$ & $\begin{array}{l}\text { Jujur, bertanggung jawab, hidup } \\
\text { sehat, disiplin, kerja keras, } \\
\text { percaya diri, berjiwa logis, kritis, } \\
\text { kreatif, inovatif, mandiri, ingin } \\
\text { tahu, dan cnta ilmu. }\end{array}$ \\
\hline $\mathbf{3}$ & $\begin{array}{l}\text { Sadar akan hak dan kewajiban } \\
\text { diri sendiri dan orang lain, patuh } \\
\text { pada aruran-aturan sosial, } \\
\text { menghargai karya dan prestasi } \\
\text { orang lain, bersikap santun, dan } \\
\text { demokrasi. }\end{array}$ \\
\hline $\mathbf{4}$ & $\begin{array}{l}\text { Keperdulian dan kekaguman } \\
\text { terhadap keindahan alam yang } \\
\text { diciptakan oleh sang pencipta. }\end{array}$ \\
\hline
\end{tabular}

Dari tabel di atas, diketahui bahwa melalui struktur novel Ayat Ayat cinta dapat diperoleh nilai-nilai moral yang menunjukkan adanya dimensi manusia dengan tuhan, dimensi manusia dengan diri sendiri dimensi manusia dengan manusia, dan dimensi manusia dengan lingkungan.

\section{Pembahasan}

Tema dalam novel Ayat Ayat cinta digambarkan oleh pengarang melalui dialog, perbuatan dan pikiran pengarang. Tema tersebut adalah keperdulian dan cinta. Keperdulian dan cinta ini merupakan ide pokok yang mendasari cerita novel. Tema ini mengingatkan kepada semua orang untuk memiliki sikap perduli terhadap sesama manusia dan mengajarkan bagaimana cinta yang sebenarnya, cinta yang berlandaskan ketaqwaan kepada Allah. Tema keperdulian dan cinta ini merupakan ide pokok yang gagasan, ide, atau pikiran utama yang mendasari suatu karya sastra. Ada kalanya tema dinyatakan dengan jelas secara eksplisit (Sudjiman, 1991:50).

Alur merupakan rangkaian cerita yang terdapat dalam novel. Alur yang digunakan pengarang dalam novel Ayat Ayat Cinta adalah alur maju, walaupun terdapat beberapa alur mundur, itu hanya sebagai variasi yang digunakan pengarang dalam menyampaikan ceritanya agar lebih menarik. Sehingga dapat memberikan kemudahan bagi 
pembaca untuk memahami ceritanya. Sesuai dengan pendapat Aminuddin berpendapat bahwa, "Alur adalah rangkaian peristiwa yang dibentuk oleh tahapan-tahapan peristiwa sehingga menjalin suatu peristiwa yang dihadirkan oleh para pelaku dalam suatu cerita (2004:83). Selanjutnya J. Arthur Honeywell dalam Hoffman berpendapat bahw plot merupakan urutan peristiwa dimana sebuah cerita dibuat yang mempunyai unsur fiksi hubungan sebab akibat satu sama lainnya (1988:239). Tokoh adalah pelaku perbuatan yang fungsinya sebagai pembentuk peristiwa sehingga menjalin sebuah cerita, yang gambaran wataknya dapat dilihat dari perbuatan, ucapan, gambaran fisik, dan pikiran-pikirannya. Dalam cerita Ayat Ayat Cinta tokoh dan penokohan ditampilkan dalam kehidupan sehariharinya tidak hanya mengetahui mengenai moral saja, tetapi tokoh-tokoh tersebut ditampilkan bisa merasakan moral dan dapat melakukan tindakan moral.

Latar adalah peristiwa dalam karya fiksi, baik berupa tempat, waktu, maupun peristiwa. Latar dibagi menjadi tiga macam, yaitu latar tempat, latar waktu, dan latar sosial. Latar tempat dapat memberikan penjelasan mengenai tempat, lokasi, wilayah atau daerah terjadinya cerita. Latar waktu dapat memberikan penjelasan mengenai waktu, masa atau zaman terjadinya cerita. Sedangkan latar sosial dapat memberikan deskripsi mengenai kondisi masyarakat yang terdapat dalam novel Ayat Ayat Cinta. Latar dalam cerita Ayat Ayat Cinta yaitu adanya latar tempat yang bermula di Mesir Kairo Al-Azhar, kemudian di flat, masjid, metro, pasar Sayeda, restoran, Alexandria, penjara, dan rumah sakit. Latar tempat yang digunakan pengarang memang benar nyata dan ada sampai dengan sekarang. Latar waktu menunjukkan waktu pagi, siang, sore, dan malam hari. Sedangkan latar sosial menunjukkan kondisi masyarakat tempat terjadinya cerita yaitu Kairo. Dalam cerita $A A C$ digambarkan keadaan masyarakatnya yang ramah, saling menghargai, menghormati, satu sama lainnya sekalipun agama yang dianut berbeda. Dalam berinteraksi selalu merujuk pada Al-Quran.

Berdasarkan struktur novel $A A C$ di atas, maka diperoleh nilai-nilai moral. Nilai-nilai moral yang ditemukan yaitu, adanya dimensi manusia dengan Tuhan yang meliputi religious; taqwa, iman, dan tawaduk. Adanya dimensi manusia dengan diri sendiri meliputi jujur, bertanggung jawab, hidup sehat, disiplin, kerja keras, percaya diri, berjiwa logis, kritis, kreatif, inovatif, mandiri, dan ingin 
tahu. Dimensi manusia dengan manusia meliputi sadar akan hak dan kewajiban diri sendiri dan orang lain, patuh pada aruran-aturan sosial, menghargai karya dan prestasi orang lain, bersikap santun, dan demokrasi. Sedangkan dimensi manusia dengan lingkungan adanya keperdulian dan kekaguman terhadap keindahan alam yang diciptakan oleh sang pencipta.Nilai moral yang ditemukan mencakup sesuai aspek yang ada, ini disebabkan karena Habiburrahman ingin karya yang dihasilkannya tidak hanya berfungsi sebagai hiburan saja, namun dapat menjadi teladan bagi pembaca, sehingga pembaca tidak hanya sekedar mengetahui tentang moral, akan tetapi dapat merasakan dan menerapkannya dalam kehidupan sehari-hari.

Nilai-nilai moral yang diperoleh Nilai moral ditinjau dari sudut latar sosial pengarang yang mengkondisikan lahirnya novel Ayat-ayat Cinta, karya Habiburrahman El Shirazy yaitu adanya dimensi manusia dengan Tuhan yang meliputi taqwa, iman dan tawaduk. Dimensi manusia dengan dirinya sendiri meliputi jujur, disiplin, kerja keras, berjiwa logis dan kritis, kreatif, mandiri, dan sabar. Dimensi manusia dengan sesama manusia meliputi sadar akan hak dan kewajiban, santun, berbakti kepada oramg tua, menghargai orang lain. Nilainilai moral tersebut diperoleh sesuai dengan latar sosial pengarang yang mengkondisikan lahirnya novel Ayat-ayat Cinta. Nilai-nilai moral yang ditemukan terdapat kesesuaian dengan teori dan cocok untuk diajarkan kepada siswa sehingga dapat membantu pembentukan karakter siswa. Melalui novel-novel ini Habiburrahman terlihat memiliki perhatian yang besar pada generasi muda mahasiswa sekarang yang malas, mudah mengeluh dan menyerah terhadap keadaan dan berbagai persoalan yang dihadapi. Tidak jarang akhirnya mengambil keputusan yang berdampak negatif dan menimbulkan permasalahanpermasalahan yang membuat resah orang tua, dan masyarakat. Habiburrahman menunjukkan sikap yang seharusnya dimiliki oleh mahasiswa dalam menggapai cita-citanya. Sikap disiplin, kerja keras, dan bertanggung jawab.

Pandangan dan pemikiran Habiburrahman mengenai pendidikan dalam novel Ayat Ayat Cinta digambarkan secara jelas melalui tokoh-tokoh rekaannya. Dalam Ayat Ayat Cinta pandangan jawab, dan sabar dalam menghadapi masalah sudah seharusnya dimiliki oleh setiap generasi muda.dan pemikiran pengarang mengenai pendidikan sangat penting. Sudah seharusnya setiap mahasiswa mengambil sikap semagat, teguh pendirian dan tekun dalam belajar dalam kondisi apapun, serta 
mengajak semua kaum pelajar, khususnya mahasiswa untuk memiliki tujuan hidup dengan membuat peta konsep sehingga tenaga dan waktu tidak sia-sia.

Dari analisis nilai moral dalam novel-novel karya Habiburrahman (Tinjauan struktural genetik), maka dapat disimpulkan sebagai berikut: (1).Nilainilai moral yang terdapat dalam struktur novel Ayat Ayat Cinta, yaitu menunjukkan adanya dimensi manusia dengan tuhan mencakup iman, takwa, dan tawaduk, dimensi manusia dengan dirinya sendiri, meliputi meliputi percaya diri, berpikir logis, kritis dan sabar. Sedangkan dimensi manusia dengan manusia meliputi sadar akan hak dan kewajiban diri sendiri dan orang lain, bersikap santun, serta penolong.. (2). Nilai-nilai moral yang diperoleh Nilai moral ditinjau dari sudut latar sosial pengarang yang mengkondisikan lahirnya novel Ayat-ayat Cinta karya Habiburrahman El Shirazy yaitu adanya dimensi manusia dengan Tuhan yang meliputi taqwa, iman dan tawaduk. Dimensi manusia dengan dirinya sendiri meliputi jujur, disiplin, kerja keras, berjiwa logis dan kritis, kreatif, mandiri, dan sabar. Dimensi manusia dengan sesama manusia meliputi sadar akan hak dan kewajiban, santun, berbakti kepada oramg tua, menghargai orang lain. (3)
Dari sudut pandangan dunia pengarang dalam novel Ayat-ayat Cinta, diperoleh nilai-nilai moral. Nilai-nilai moral tersebut yaitu adanya dimensi manusia dengan Tuhan yang meliputi taqwa, iman dan tawaduk. Dimensi manusia dengan dirinya sendiri meliputi jujur, disiplin, kerja keras, berjiwa logis dan kritis, kreatif, mandiri, dan sabar. Dimensi manusia dengan sesama manusia meliputi sadar akan hak dan kewajiban, menghargai orang lain.

Berdasarkan temuan dan kesimpulan penelitian yang dipaparkan di atas, disarankan kepada: (1) Pihak sekolah terutama guru Bahasa Indonesia hendaklah novel Ayat-ayat Cinta karya Habiburrahman El Shirazy dapat digunakan sebagai bahan alternatif pembelajaran apresiasi sastra di tingkat SMA karena sarat dengan nilai-nilai moral yang dapat menambah wawasan dan pengetahuan baru. (2) Guru Bahasa Indonesia hendaklah dalam penyampaian materi tidak hanya menekankan pada teori saja, tetapi melatih peserta didik agar dapat mengapresiasi karya sastra, sehingga melalui karya sastra dapat membentuk karakter atau kepribadian peserta didik yang bermoral. (4)Peserta didik hendaknya memperkaya buku bacaan sastra lainnya agar dapat menemukan nilai-nilai moral yang 
terkandung dalam bacaan tersebut sehingga membantu pembentukan karakter peserta didik menjadi lebih baik, dan (4) Mahasiswa Jurusan Pendidikan Bahasa dan Sastra Indonesia hendaknya melestarikan sastra dan mengembangkannya melalui pendekatan moral.

\section{DAFTAR PUSTAKA}

Aminuddin. 1990. Pengembangan Penelitian Kualitatif: Dalam Bidang Bahasa dan Sastra. Malang: Yayasan Asih Asah Asuh.

Arikunto, Suharsimi. 2002. Prosedur Penelitian: Suatu Pendekatan Praktek. Jakarta: RinekaCipta.

Eagleton, Terry. 2007. Teori Sastra: Sebuah Pengantar Komprehensif. Bandung: Jalasutra.

El Shirazy, Habiburrahman. 2004. AyatAyat Cinta. Jakarta : Republik dan Pesantren Basmala Indonesia.

Cinta Bertasbih. Jakarta : Republik dan Pesantren Basmala Indonesia.

2011. Bumi

Cinta. Jakarta : Republik dan Pesantren Basmala Indonesia.

, dkk. 2013.

Catatan Motivasi Seorang Santri. Jakarta: Kangabik.com dan Santri.

Emzir. 2010. Metodologi Penelitian Kualitatif Analisis Data. Jakarta: Rajawali,

2010.

Metodologi Penelitian Kualitatif Analisis Data. Jakarta: Rajawali.

Endraswara, Suwardi. 2008. Metodologi Penelitian Sastra : Epistemologi, Model, Teori, dan Aplikasi. Yogyakarta: Med Press (Anggota IKAPI), 2

. 2012. Teori

Pengkajian Sosiologi Sastra.

Yogyakarta: UNY Press.

Faruk. 1994. Pengantar Sosiologi Sastra:

Dari Strukturalisme Genetik Sampai Post-Modernisme.

Yogyakarta: Pustaka Pelajar.

Fenanie, Zainuddin. 2001.Telaah Sastra. Surakarta: Muhammadiyah University Press.

Goldmann, Lucien. 1975. Towards A Sociology of The Novel. London:Tavistock.

Hidayatullah, M. Furqon. 2010. Pendidikan Karakter: Membangun Peradaban Bangsa. Surakarta: Yuma Pustaka.

Hoffman, Michael J and Murphy Patrick D. 1988. Essentials of The Theory of Fiction. Durham and London: Duke University.

Klarer, Mario. 2004. An Introduction to Literary Studies. London and New York : Roudledge.

Kutha Nyoman, Ratna. 2009. PenelitianSastra: Teori, Metode, danTeknik. Yoyakarta: Pustaka Pelajar.

Lickona, Thomas.1991. Educating for Character. New York : Bantam Books, 
Luxemburg, Jan Van dkk. 1991. TentangSastra. Jakarta: Intermasa.

Mayring, Philipp. Qualitative Content Analisisdalam Forum: Qualitatif Social Recearch, ol. 1. Nomor 2 Junitahun 2000 , tersediadalamsitus htpp://www.qualitativeResearch.n et/fqs-texte/2-00mayring-e-htm (20/8/2003).

Moleong, Lexy J. 2005. Metodologi Penelitian Kualitatif. Bandung: PT Remaja Rosdakarya.

Mujib El Shirazy, Ahmad. 2009. The Inspiring Life Of: Habiburrahman El Shirazy. Jakarta; PT. Balai Pustaka (Persero).

Nurgiyantoro, Burhan. 2010. Teori Pengkajian Fiksi. Yogyakarta; Gadjah Mada University Press.

Samani, Muchlas dan Hariyanto. 2012. Pendidikan Karakter. Bandung : PT Remaja Rosdakarya.
Semi, Antar. 1989. Kritik Sastra. Bandung: Angkasa. Metode Penelitian Sastra. Bandung: Angkasa, 2012.

Sirsaeba El Shirazy, Anif. Fenomena Ayat Ayat Cinta. Jakarta: Republika dan Pesantren Basmala Indonesia, 2007.

Spradly, James P. Participant Observation. New York: Holt Rinehart and Winston, 1980.

Stanton, Robert. 2007. Teori Fiksi. Yogyakarta: Pustaka Pelajar.

Sudjiman, Panuti. 1991. Memahami Cerita Rekaan. Jakarta : Pustaka Jaya.

Sumardjo, Jakob. Memahami Kesusastraan. Bandung: Alumni, 1984..

Wellek, Rene dan Austin Warren.1990.Teori Kesusastraan (Penerjemah: Melani Budianta). Jakarta: Gramedia.

Yahya, Harun. 2002. Moralitas al-Quran: Solusi atas segala persoalan umat manusia. Jakarta: Robbani Press. 